\title{
Effect of Plant Extracts on Seed Borne Fungi of Jute
}

\author{
Md. Abdul Ahad ${ }^{1}$, Md. Shahidul Islam ${ }^{2 *}$, Nur Fatema Nupur ${ }^{3}$ \\ ${ }^{1}$ Department of Plant Pathology, Bangladesh Agricultural University, Mymensingh, Bangladesh \\ ${ }^{2}$ Department of Plant Pathology, Yunnan Agricultural University, Kunming, China \\ ${ }^{3}$ Department of Fisheries Management, Bangladesh Agricultural University, Mymensingh, Bangladesh \\ Email: *shahidul.uni@gmail.com
}

How to cite this paper: Ahad, Md.A. Islam, Md.S. and Nupur, N.F. (2018) Effect of Plant Extracts on Seed Borne Fungi of Jute. American Journal of Plant Sciences, 9, 2580-2592.

https://doi.org/10.4236/ajps.2018.913187

Received: October 18, 2018

Accepted: December 4, 2018

Published: December 7, 2018

Copyright (c) 2018 by authors and Scientific Research Publishing Inc. This work is licensed under the Creative Commons Attribution International License (CC BY 4.0).

http://creativecommons.org/licenses/by/4.0/

\section{(c) (i) Open Access}

\begin{abstract}
The aim of this study was to determine the prevalence of seed-borne fungal pathogens of jute and their control with plant extract. The experiment was carried out in seed pathology centre, Bangladesh Agricultural University to obtain relevant information about the health of jute seeds and find out the efficacy of extracts as seed-treater. Two varieties viz., Deshipat (Corchorus capsularis) and Tossapat (Corchorus olitorius) were selected for this study and jute seeds were collected from two different locations of Bangladesh. The major predominant identified fungi were Colletotrichum corchori, Macrophomina phaseolina, Fusarium spp., and Botryodiplodia theobromae. Least seed-borne fungi were found in the variety of Tossapat. Low germination of seeds was found related to high prevalence of seed-borne fungal infections. Highest seed-borne infection was obtained in the variety of Deshipat. In this study, we evaluated some major plant extracts such as garlic clove (Allium sativum), neem leaves (Azadirachta indica), allamanda leaves (Allamanda cathartica L.) and marigold leaves (Tagetes spp.) for observing the action of these plant extracts on seed borne fungi of Jute. The study revealed that the extract of Garlic (Allium sativum), and Biskatali (Polygonum hydropiper) increased the germination of seeds and garlic (Allium sativum) extract was also found to be most effective in controlling the seed-borne infection among all the treatments. Although the inhibiting capacity of the extracts of Allamanda (Allamanda cathartica L.) and Biskatali (Polygonum hydropiper) was found to be similar and Biskatali extract was found to have the second position among all the treated plant extracts in inhibiting the growth of isolated fungal pathogens.
\end{abstract}

\section{Keywords}

Botanical Treatment, Medicinal Plant, Bio-Control, Seed, Jute 


\section{Introduction}

Jute (Corchorus capsularis L. and C. olitorius L.) is the main cash crop of Bangladesh and it has a great influence on socio-economic life of jute farmers in Bangladesh. Bangladesh supplies about $70 \%$ jute and related product to the global market [1]. As a single producer and exporter, Bangladesh possesses second position among Jute exporting countries. Although Jute is main cash crop of Bangladesh [2] and it earns foreign exchange by exporting jute and jute goods, there is a great scarcity of quality of healthy jute seeds in Bangladesh [3]. Jute suffers from a number of diseases. Of all the diseases of jute, 10 are known to be seed borne. Among the seed-borne fungal diseases, stem-rot, black band and anthracnose caused by Macrophomina phaseolina, Botryodiplodia theobromae and Colletotrichum corchori respectively are frequently transmitted through jute seeds. Stem rot, black band, anthracnose, foot rot and wilt (Rhizoctonia solani) are responsible for seed rot, pre and post emergence damping off, seedling infections and spread of the diseases to standing crops causing considerable yield loss [4] and deterioration in the quality of fiber [5]. Seed-borne pathogens causing diseases on the growing jute plants in the field quite often attack the capsules or pods and subsequently infect the seed, resulting in the production of infected or unhealthy seeds [6] [7]. Therefore, proper disease control measure should be taken for the production of quality healthy jute seeds [8]. Proper disease management practices can substantially improve the quality of jute and significantly increase the yield [9] [10]. Among the practices used, seed treatment is probably the cheapest and safest method of direct plant disease control [7]. In many countries regular practice of seed treatment is considered as an insurance against the building up of inoculant and has greatly reduced the yield loss and improves the quality in many crops [11] [12], once chemical control of plant diseases was quite popular for reducing crop losses [13]. But now-a-days use of chemical for management of crop diseases is being discouraged due to health hazard [14] and environmental pollution [15] and the obvious development of tolerant pathogen [16]. In addition, the fungicides are very expensive that is sometimes burden for the poor farmers [17]. In addition, their harmful effect is responsible for air, soil and water pollution. Alternative means of seed treatment i.e., use of environmentally friendly botanical pesticides or plant extract have drawn the attention of Plant Pathologists all over the world [18]. Use of plant extracts for seed treatment may open a new area in controlling seed-borne fungal pathogens. Only a few plant species have so far been tested for controlling the seed-borne fungal pathogens of jute by treating the seed. In view of the above facts, the present study was undertaken to determine the prevalence of seed-borne fungal pathogens and germination condition in selected varieties of jute seeds.

\section{Materials and Method}

The experiment is carried out in seed pathology center, Bangladesh Agricultural 
University to obtain relevant information about the health of jute seeds and find out the efficacy of extracts as seed-treater.

\subsection{Collection of Jute Seed Samples}

A total of 40 seed samples of jute (Corchorus capsularis L.) of local variety, Deshipat and Tossapat (Corchorus olitorious) were collected from two different locations of Bangladesh (Netrokona sader and Barhatta sader upazilla). In this experiment, ten villages (Amtola, Mudonpur, Sapmara, Parla, Ruhi, Forgati, Satorcree, Simulgani, Faridpur and Sinharbangla) under Netrokona sader upazilla and ten villages (Asma, Serum, Borhati, Laufull, Hazigonj, Muitor, Bori, Otitpur, Islampurm and Chandreepur) under Barhatta sader upazilla' were taken as study areas. One sample was collected from each village in case of two varieties. The size of each sample was $500 \mathrm{~g}$ (approx.). The seeds were then kept in polythene bags and stored in the Seed Store of the Seed Pathology Laboratory at $5^{\circ} \mathrm{C}-7^{\circ} \mathrm{C}$, till these were used for the subsequent studies.

\subsection{Identification of Seed-Borne Fungi Associated with Jute Seeds}

All the seed samples were assayed for the presence of fungal pathogens by the Blotter Method following the International Rules for Seed Testing Association [19].

\subsection{Blotter Method for Evaluating Seed Health Status of Jute Seed}

Seed health status was carried out by Blotter method to detect the seed borne pathogens associated with the jute seed samples. In this method, two hundred seeds were randomly taken from each sample. The seeds were planted on water soaked three layered Whatman No. 1 filter paper in plastic petridishes. In each Petridis, 25 seeds were plated at equal distance. All these petridishes were incubated at $20^{\circ} \mathrm{C} \pm 2{ }^{\circ} \mathrm{C}$ under $12 \mathrm{hrs}$, alternate cycle of Near Ultra Violet (NUV) light and darkness [20]. After 7 days of incubation, petriplates containing incubated seeds were observed under stereomicroscope for detecting seed borne pathogens on jute seed surface under stereomicroscope at $25 \times$ magnification. Where identification was difficult or doubtful under the stereomicroscope, temporary slide was prepared and examined under the compound microscope and identified with the help of literature review and expert consultation. Number of germinated seeds was recorded along with the seed-borne fungi after seven days of incubation. The results were expressed in percentage.

\subsection{Germination Test}

Four hundred seeds were taken randomly from the well-mixed seed sample (1STA, 1999). The working samples were divided into four replications and thus one replication contained 100 seeds. To ensure adequate spacing, 10 seeds were divided into four sub replications and each sub replication contained 25 seeds. The filter papers were germinated on top of three layers of Whatman No. 1 filter paper. The filter papers were soaked in water and placed at the bottom of $9 \mathrm{~cm}$ 
diameter plastic petridishes and thereafter 25 seeds were placed on the top of filter paper. Thus 400 seeds were placed in 16 replicate petridishes. Evaporation of water was minimized by tightly fining the lids of the petridishes. The petridishes were placed inside the incubator maintaining the temperature at $30^{\circ} \mathrm{C}$ for five days [3]. Seeds producing both plumule and radical after incubation were counted as germinated seeds. The result was expressed as percentage.

\subsection{Seed Treatment with Plant Extracts}

The major plant extracts $(1: 2 \mathrm{v} / \mathrm{v}$ concentration) used for this experiment were garlic (clove) extract (Allium sativum), Allamanda (leaf) extract (Allamanda cathartica L.), Marigold (leaf) extract (Tagetes spp.), and Biskatali (leaf) extract (Polygonum hydropiper). Four different plant species were collected from different areas of Bangladesh Agricultural University, Mymensingh Campus which were used in this study. Twenty-five grams of each test plant was grounded in a mortar without water. The pulverized mass was squeezed through 3 folds of fine cloth and then the filtrate was used as extract. Jute seeds were treated by dipping separately different extracts of 1:2 dilutions. Just after dipping, the excess extracts were drained off and treated seeds were tested for the presence of fungal flora by the Blotter Method [19]. In case of control, seeds were treated only with sterile water.

\subsection{Analysis of Data}

The experiments were conducted following the Completely Randomized Design (CRD). Analysis of variance was done and the mean differences in the efficacy of the treatments were judged by Duncan's Multiple Range Test (DMRT). The percentage value of the prevalence of seed borne fungi, the efficacy of plant extract treatments was transformed by Arcsin transformation technique before analysis of variance [21]. In case of prevalence value of total seed borne fungi was not transformed, because the values obtained in some cases were above $100 \%$.

\section{Results of the Study}

\subsection{Identification of Seed-Borne Fungi Associated with Jute Seeds}

After 7 days of incubation of seeds on wet blotting paper the yielded fungi were detected and then identified by the standard blotter method. The fungi yielded were Macrophomina phaseolina, Botryodiplodia theobromae, Colletotrichum corchori, Cercospora corchori, Curvularia lunata, Fusarium spp., Aspergillus spp., and Penicillium spp. Among them only the major ones were considered in this experiment (Figures 1-4).

\subsection{Effects of Seed-Borne Fungi on the Germination of Seeds}

After 7 days of incubation, viability of seed samples recorded reveals that the germination ranges from $53.00 \%$ to $69.00 \%$. The seed samples obtained from 


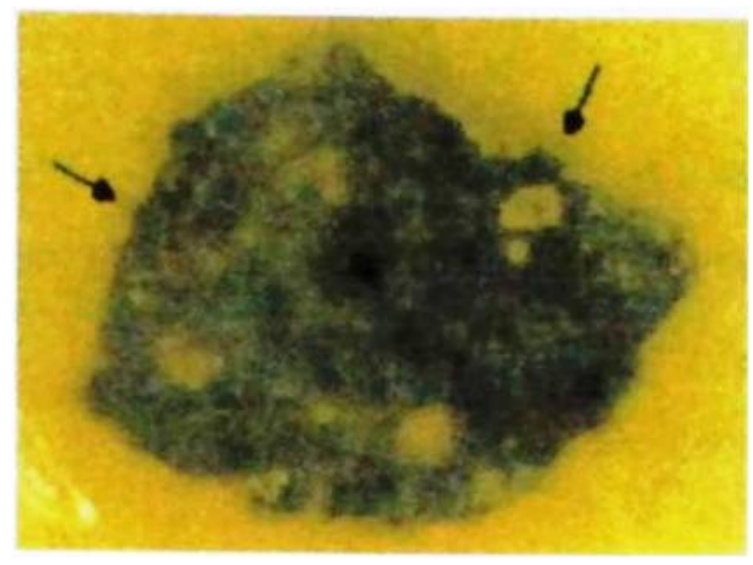

Figure 1. Setae and acervuli of Colletotrichum corchori on jute seed.

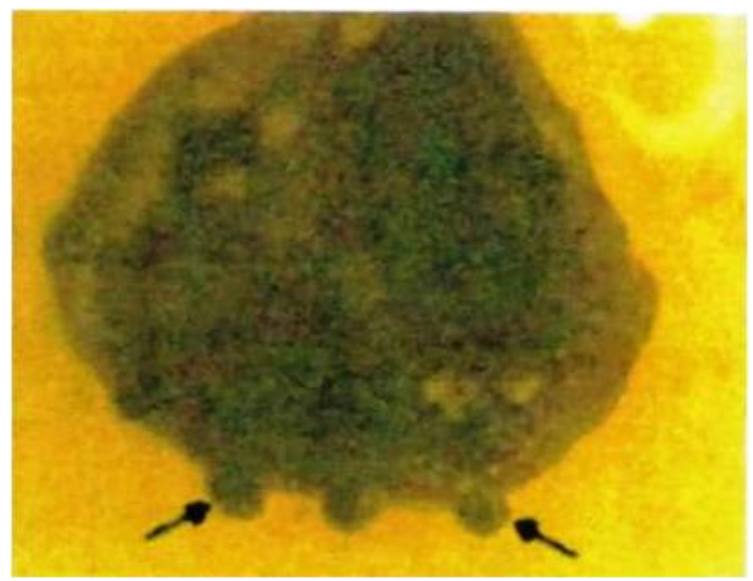

Figure 2. Pycnidia of Macmphomina phaseolina on jute seed.

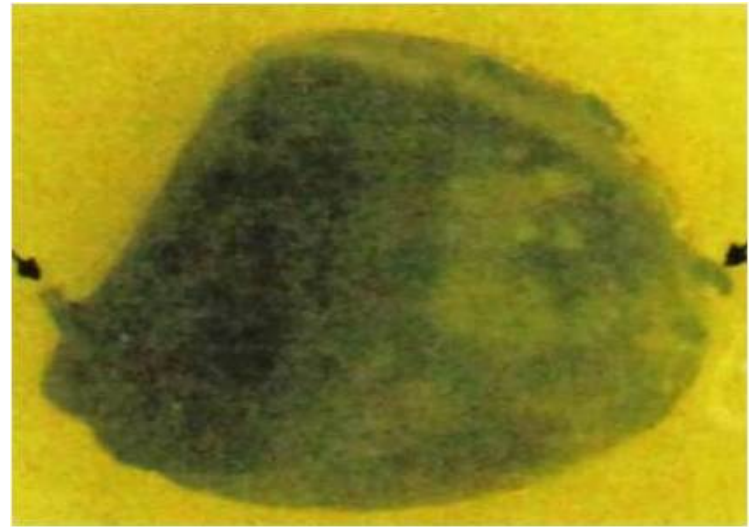

Figure 3. Cirrus of pycnidia of Botryodiplodia theobromae jute seed.

Barhatta sader upazila showed highest percentage of germination (69.00\%). A significant difference in germination percentage among the seed samples was observed. 


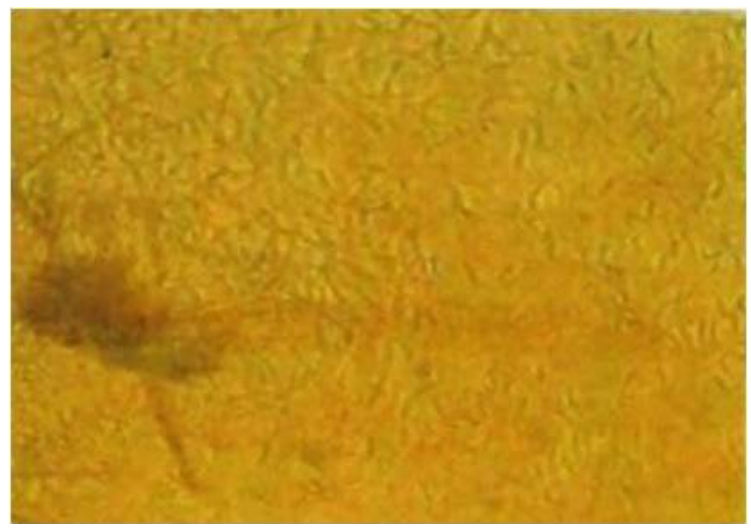

Figure 4. Conidia and setae of Colleugricum corchori.

\subsection{Prevalence of Seed-Borne Fungi Associated with the Jute Seeds}

The germination of seeds and incidence of fungi associated with the seeds of two jute varieties viz. Deshipat and Tossapat collected from two different locations of Bangladesh viz. Netrokona and Barhatta sader upazilla. After incubation of seeds on blotter, seven major seed-borne fungi such as Colletotrichum corchori, Macrophomina phaseolina, Botryodiplodia theohromae, Fusarium spp., Aspergillus spp., and Penicillium spp. were found. The germination percentage of jute seeds differed significantly from variety to variety and also location to location. Seed germination of jute variety, Tossapat was significantly higher followed by Deshipat $(60.95 \%)$ and presented in Table 1.

Seed collected from Barhatta sader upazilla in the villages of Hazigonj and Asma showed the highest germination (69.00\%) followed by Netrokona sader upazilla in the village of Parla (67.50\%).

\subsection{Variation of Infection of Seed-Borne Fungi}

This seed sample was studied following standard blotter method. Four plant extracts namely, Garlic (clove) extract (Allium sativum), Allamonda (leaf) extract (Allamanda cathartica L.), Marigold (leaf) extract (Tagetes spp.), and Biskatali extract (Polygonum hydropiper) were used in this experiment. Since the Curvularia lunata, Cercospora corchori, Rhizopus spp., were not found as major seed-borne fungi of jute and not included in this experiment. $42.46 \%$ seed-borne infection was recorded in the jute seeds. The treated seeds showed significantly higher rate of germination than untreated seeds.

\subsection{Seed Germination}

All the treatment used in the experiment significantly increased the germination of jute seeds compared to untreated control. The highest germination (80.50\%) was obtained in both $\mathrm{T}_{1}$ (Garlic extract) and $\mathrm{T}_{4}$ (Biskatali extract) which were statistically similar with the treatment $\mathrm{T}_{3}$ (Marigold extract). It also revealed that $72.00 \%$ germination was recorded in $\mathrm{T}_{\mathrm{o}}$ (Control) which was significantly lower than the rest of all the treatment. 
Md. A. Ahad et al.

Table 1. Effect of variety on seed germination and seed-borne pathogens.

\begin{tabular}{cccccccccc}
\hline Variety & $\begin{array}{c}\text { Germination } \\
(\%)\end{array}$ & $\begin{array}{c}\text { Colletotrichum } \\
\text { corchori }\end{array}$ & $\begin{array}{c}\text { Macrophomina } \\
\text { phaseolina }\end{array}$ & $\begin{array}{c}\text { Botryodiplodia } \\
\text { theobromae }\end{array}$ & $\begin{array}{c}\text { Fusarium } \\
\text { oxysporum }\end{array}$ & $\begin{array}{c}\text { Aspergillus } \\
\text { niger }\end{array}$ & $\begin{array}{c}\text { Aspergillus } \\
\text { flavus }\end{array}$ & $\begin{array}{c}\text { Penicillum } \\
\text { spp. }\end{array}$ & $\begin{array}{c}\text { Total } \\
\text { Deshipat }\end{array}$ \\
& $60.95 \mathrm{~b}$ & $8.90 \mathrm{a}$ & $7.36 \mathrm{~b}$ & $6.57 \mathrm{a}$ & $8.52 \mathrm{a}$ & $5.47 \mathrm{a}$ & $4.45 \mathrm{a}$ & $1.19 \mathrm{a}$ & 42.46 \\
& $(51.36)$ & $(17.31)$ & $(15.7)$ & $(14.81)$ & $(16.91)$ & $(13.35)$ & $(6.32)$ & $(13.14)$ \\
Tossapat & $67.00 \mathrm{a}$ & $7.06 \mathrm{~b}$ & $8.64 \mathrm{a}$ & $5.66 \mathrm{~b}$ & $6.47 \mathrm{~b}$ & $6.09 \mathrm{a}$ & $4.57 \mathrm{a}$ & $1.52 \mathrm{a}$ & 40.01 \\
LSD & $(55.01)$ & $(15.34)$ & $(17.04)$ & $(13.65)$ & $(14.65)$ & $(14.14)$ & $(12.28)$ & $(7.02)$ \\
P $\leq 0.01$ & 5.27 & 0.83 & 0.82 & 0.81 & 0.84 & 0.82 & 0.85 & 0.69 & \\
\hline
\end{tabular}

Note: Column having the same letter(s) are statistically identical; figures in parentheses indicate the transformed values and four hundred seeds were tested for each sample.

\subsection{Efficacy of Plant Extracts on Seed-Borne Infection}

The efficacy of plant extracts in controlling seed-borne infection was analyzed (Figure 5). The results showed that effect of treatments in controlling seed-borne fungi was statistically significant. Extract from T3 (Marigold extract) was also found to be more effective in controlling the seed-borne infection by Colletotrichum corchori. T1 (Garlic extract) was statistically similar with the treatment T2 (Allamonda extract). In controlling Macrophomina phaseolina, extract of garlic and Allamanda appeared to be the best showing inhibition and then in a descending order, the extract of Marigold and Biskatali showed $4.00 \%$ and $4.00 \%$, $3.5 \%$ infection respectively. In respect of the inhibition effects of different plant extracts used, no significant differences were observed between Garlic and Allamanda and between the extract of Marigold and Biskatali. But Botryodiplodia theobromae was found completely controlled by all the test plant extracts except the extract of Garlic (Allium sativum) and Biskatali (Polygonum hydropiper) respectively.

There was no significant difference among the extract of Allamanda (Allamanda cathartica L.) and Marigold (Tagetes spp.). In case of the inhibition of Fusarium oxysporum, the extract of Biskatali appeared to be the most effective, completely controlling the inhibition of Fusarium oxysporum among all the treatments which was statistically different and then in a descending order, the extract of Garlic, Allamanda and Marigold showed 4.00\%, 6.00\% and 9.00\% infection respectively. Extracts from Garlic and Allamanda showing $4.00 \%$ and $6.00 \%$ infection respectively and they did not exist any significant difference. Aspergillus niger was totally controlled when seeds were treated with the extract of Garlic and the growth of Aspergillus niger was also inhibited when seeds were treated with the extract of Allamonda, Marigold and Biskatali showing 2.00\%, $2.00 \%$ and $2.00 \%$, they were statistically no difference. The growth of Aspergillus flavus was totally inhibited when seeds were treated with $\mathrm{T}_{1}$ (the extract of Garlic) which was statistically different than rest of all treatments. The extract of Allamonda, Marigold and Biskatali showing $1.00 \%, 2.00 \%$ and $1.00 \%$, they were statistically no difference. In case of Penicillum spp., it was totally inhibited when seeds were treated with $\mathrm{T}_{1}$ (Garlic extract) and $\mathrm{T}_{4}$ (Biskatali extract) and they were statistically similar (Table 2 ). 


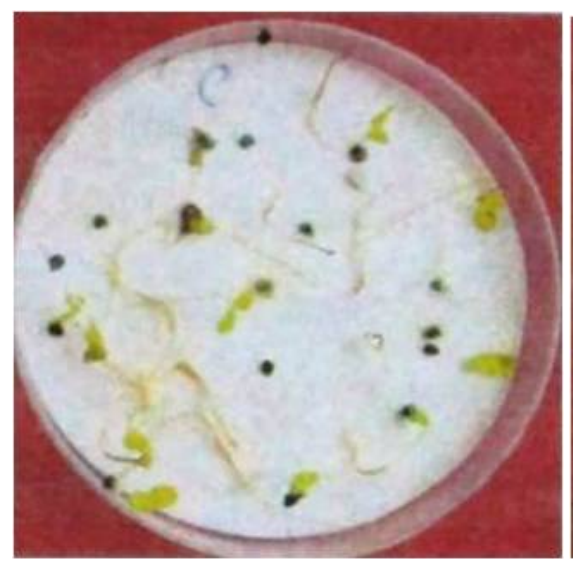

(a)

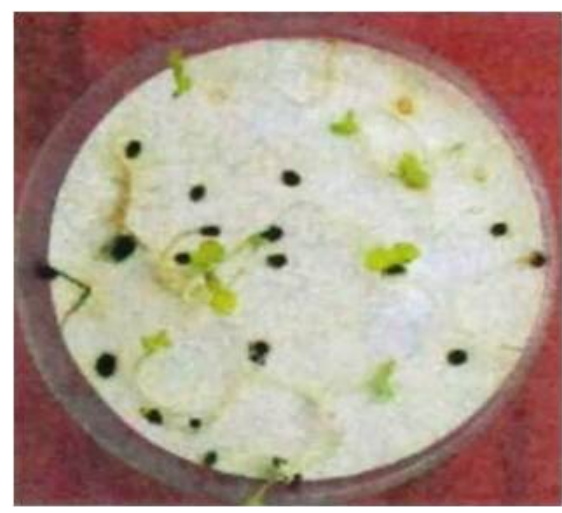

(d)

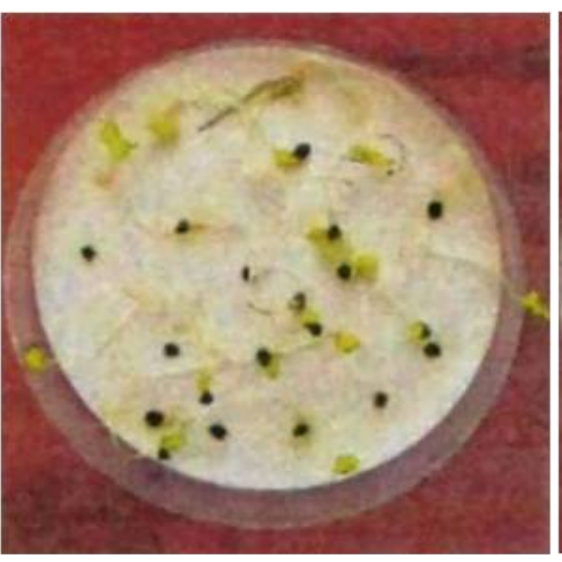

(b)

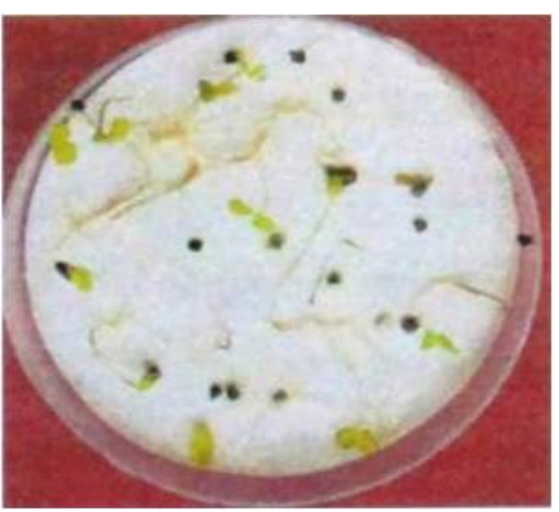

(e)

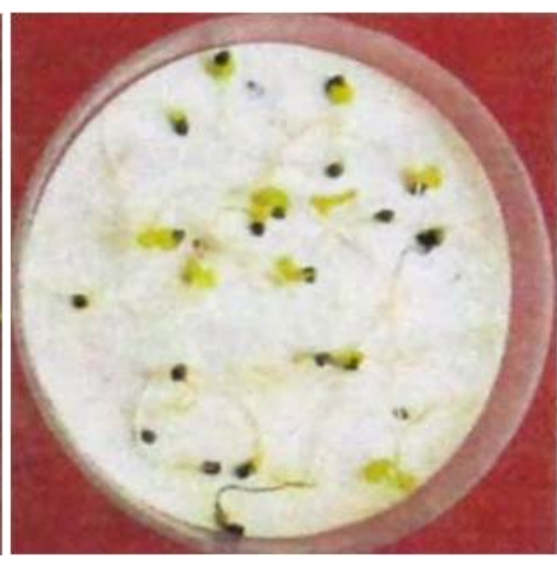

(c)

Figure 5. Effect of different plant extracts in controlling seed-borne fungi of jute seeds showing (a) Control, (b) Garlic, (c) Allamanda, (d) Marigold and (e) Biskatali treatment.

\section{Discussions}

Seed-borne mycoflora is one of the major factors of low yield of jute. So, it has a great impact on jute crop production and thus prevention of seed-borne mycoflora demands enormous importance. The present research was undertaken to achieve this goal. Results of the present investigation revealed that the jute seeds produced by farmers are quite frequently infected by fungi. In this work, the seed-borne fungi associated with some control measures were studied. Seven prevalence seed-borne fungi were detected on the seeds of jute samples collected from different locations (villages) under two local administrative unit of Netrokona district in Bangladesh. Earlier, different workers studied the fungal flora associated with the jute seeds in Bangladesh and reported that Macrophomina phaseolina, Botryodiplodia theobromae, Ascochyta corchoricola, Cercospora corchori, Colletotrichum corchori, Corynespora cassiicola, Rhizoctonia solani, Sclerotium rolfsii, Chaetomium, Curvularia lunata, Fusarium spp. and Phomopsis spp., were found to be associated with the jute seeds [6] [22]. Other than Bangladesh, many workers also reported Botryodiplodia theobromae, Macrophomina phaseolina, Colletotrichum corchori, Alternaria tenuis, Arthrobotrytis spp., Cephalosporium spp., Curvularia lunata, Fusarium spp., Periconia spp., 
Table 2. Effect of different plant extracts in controlling seed-borne pathogens. Garlic extract.

\begin{tabular}{|c|c|c|c|c|c|c|c|c|c|c|}
\hline \multirow[b]{2}{*}{ Treatments } & \multirow{2}{*}{$\begin{array}{c}\text { Germination } \\
(\%)\end{array}$} & \multicolumn{7}{|c|}{$\%$ Seed borne fungi } & \multirow{2}{*}{$\begin{array}{c}\text { Total seed } \\
\text { borne } \\
\text { fungi } \\
(\%)\end{array}$} & \multirow{2}{*}{$\begin{array}{l}\text { Reduction } \\
\text { Over control } \\
\quad(\%)\end{array}$} \\
\hline & & $\begin{array}{c}\text { Colletotrichum } \\
\text { corchori }\end{array}$ & $\begin{array}{c}\text { Macrophomina } \\
\text { phaseolina }\end{array}$ & $\begin{array}{c}\text { Botryodiplodia } \\
\text { theobromae }\end{array}$ & $\begin{array}{l}\text { Fusarium } \\
\text { oxysporum }\end{array}$ & $\begin{array}{l}\text { Aspergillus } \\
\quad \text { niger }\end{array}$ & $\begin{array}{l}\text { Aspergillus } \\
\quad \text { flavus }\end{array}$ & $\begin{array}{l}\text { Penicillum } \\
\text { spp. }\end{array}$ & & \\
\hline Garlic extract & $\begin{array}{l}80.50 \mathrm{a} \\
(63.80)\end{array}$ & $\begin{array}{l}\text { 4.00be } \\
\text { (11.49) }\end{array}$ & $\begin{array}{l}2.00 \mathrm{c} \\
(7.99)\end{array}$ & $\begin{array}{l}1.00 \mathrm{c} \\
(5.22)\end{array}$ & $\begin{array}{l}4.00 c \\
(11.49)\end{array}$ & $\begin{array}{l}0.00 \mathrm{~b} \\
(1.28)\end{array}$ & $\begin{array}{l}0.00 \mathrm{c} \\
(1.28)\end{array}$ & $\begin{array}{l}0.00 \mathrm{c} \\
(1.28)\end{array}$ & $11.00 \mathrm{c}$ & 89.00 \\
\hline $\begin{array}{c}\text { Marigold } \\
\text { extract }\end{array}$ & $\begin{array}{l}77.75 a \\
(61.86)\end{array}$ & $3.00 \mathrm{c}(9.90)$ & $\begin{array}{l}4.00 \mathrm{~b} \\
(11.49)\end{array}$ & $\begin{array}{l}0.00 \mathrm{~d} \\
(1.28)\end{array}$ & $\begin{array}{c}9.00 \mathrm{~b} \\
(17.44)\end{array}$ & $\begin{array}{l}2.00 \mathrm{~b} \\
(7.99)\end{array}$ & $\begin{array}{l}2.00 \mathrm{~b} \\
(7.99)\end{array}$ & $\begin{array}{l}1.00 \mathrm{~b} \\
(5.22)\end{array}$ & $22.00 \mathrm{~b}$ & 78.00 \\
\hline $\begin{array}{l}\text { Biskatali } \\
\text { extract }\end{array}$ & $80.50 \mathrm{a}(63.94)$ & $5.00 \mathrm{~b}(12.88)$ & $4.00 \mathrm{~b}(11.49)$ & $2.00 \mathrm{~b}(7.99)$ & $0.00 \mathrm{~d}(15.32)$ & $2.00 \mathrm{~b}(7.99)$ & $\begin{array}{l}1.00 \mathrm{~b} \\
(5.22)\end{array}$ & $\begin{array}{l}0.00 \mathrm{c} \\
(1.28)\end{array}$ & 13.00 & 87.00 \\
\hline $\begin{array}{c}\text { LSD } \\
\mathrm{P} \leq 0.01\end{array}$ & 4.82 & 1.23 & 1.23 & 0.95 & 1.23 & 1.10 & 0.95 & 0.77 & & \\
\hline
\end{tabular}

Note: Column having the same letter(s) are statistically identical, figures in parenthesis indicate (Arcsin) transformed values and four hundred seeds were tested for each sample.

and Trichotheciurn spp., to be associated with the jute seed [11] [21] [23] [24]. Ascochyta corchoricola, Rhizoctonia Chaetomium, Phomopsis spp., Alternaria tenuis, Cephalosporium spp., Periconia spp., and Trichothecium spp., were not observed to be associated with the seed samples used in the present experiment. Two possible explanations could be given to the difference between the present and the earlier results: Firstly, the seed samples collected from the specific locations, used in this experiment does not have the additional fungal flora observed by the earlier workers. Secondly, the differences in the number of samples used by them and in the present experiment might be a cause of not having the additional fungal flora. So far the germination of seed is concerned the results corroborate with the findings of different workers showing that the fungi associated with seeds affect the germination of seeds [3] [18] [25] [26] [27]. Islam et al. [27] reported that the fungi associated with the jute seeds reduced the germination of seeds. Among the two categories of jute seed-Deshipat and Tossapat, Deshipat (60.95\%) had the poorest germination compared to Tossapat (67.00\%). This may be due to genetic causes (Add reference). Health condition of the Tossapat was the best as it had relatively lower (40.01\%) total seed-borne infection. Poor germination of Deshipat as regard to germination and seed-borne infection was probably due to less care taken by the farmers during seed crop management, seed processing and storage after harvest. In the present findings, more or less significant difference was observed in germination percentage between the seed samples. This difference might be due to the procedural differences in sample collection, differences in as well as the quantity and kinds of seed-borne fungal flora associated with them. The pathogens encountered were Botryodiplodia theobromae, Colletotrichum corchori, Curvularia lunata, Fusarium spp., and Macrophomina phaseolina. In present finding, it was observed that besides three destructive pathogens, other pathogens were viz., Fusarium oxysporum and Penicillum spp. were also observed. The species of Fusarium oxysporum encountered in the present study were found to be responsible for seed germination failure. Frequent association of Fusarium oxysporum with jute seeds and its 
demonstrated pathogenic potentiality of causing seed rot/germination failure and seedling blight to the crop, indicates that Fusarium oxysporum might also be a potential seed borne pathogen causing some diseases like wilt in the growing jute crop in the field [28]. Aspergillus species were quite frequently associated with the jute seeds and the fungi were also recorded in geminated/rotted seeds in wet blotter [29]. This indicates that the two storage fungi might affect the health of jute seeds. However, other factors might also be responsible for the seed rot/germination failure. High frequency of Aspergillus spp., in jute seeds and its association with rotted seeds on wet blotter observed in the present study demands further critical study on the possible role of these two storage fungi on the health of jute seeds [30]. The incidence of Penicillum spp. was the lowest among the fungi detected in the present investigation. A few seed samples were found infected with Penicillum spp. out of 40 seed samples. This might be due to Penicillum free seeds used by the farmers, lower inoculum potential and lower infection of the crop in the farmer's field.

In present findings, more or less significant differences were observed in the percentage germination of two jute varieties collected from two different locations of Netrokona district. Results showed that none of the samples out of 40 had germination higher than $80 \%$ i.e., national standard. This might be due to improper handling and processing of seeds after harvest, differences in storage condition and kinds of seed-borne fungi associated with them [6] [31] [32]. It is expected to be a logical phenomenon that the percent seed-borne infection will be reduced and percent germination will be increased due to seed treatment. In present study, all the treatments were significantly higher over control. This has the supports of the observation made by a good number of researcher like [3] [9] [28]. In the experiment where different plant extracts were used in controlling seed-borne fungi of jute, the seeds treated with garlic extract (Allium sativum) showed highest germination percentage which corroborate with the results of [3] [6] [18] [27] [28] who worked with other crop seeds. The extract of leaf of allamanda leaf extract also found to significantly increase the germination percentage over the control treatment. This is also in agreement with the findings of Islam et al. [3] where he used the extract of allamanda on eggplant seeds. In the present study marigold (Tagetes erecta) appeared to be less effective against Macrophomina phaseolina, Colletotrichum corchori, Fusarium oxysporum but more effective against Botryodiplodia theobromae and Penicillum spp. whereas Islam [24] found marigold effective against Gerlachia oryzae, Pyricularia oryzae and Rhizoctonia solani. The extract of Biskatali effectively controlled Fusarium oxysporum and Penicillum spp.

From the present study, it was observed that seed borne fungi are a threat to the health of jute seeds. Thus, situation demands that due attention should be paid to health status of jute seeds prior to sowing. Seed treatment may be a unique technique applicable in this regard as it reduces or eliminates seed borne mycoflora and also increases seed germination. But the study of one season and only laboratory experiment is not sufficiently enough. This emphasizes the need 
of undertaking further comprehensive research with more varieties and chemicals and field study for its confirmation.

\section{Conclusion}

The study intended to explore the efficacy of plant extract on the control of fungi infected seed borne diseases on jute. The Deshipat (Corchorus capsularis) and Tossaha pat (Corchorus olitorius) were chosen for this study. The major four plant extracts ( $1: 2 \mathrm{v} / \mathrm{v}$ concentrations) were used for this experiment such as garlic (clove) extract, Allamanda (leaf) extract, Marigold (leaf) extract, and Biskatali (leaf) extract. The study reveals that the major predominant identified fungi were Colletotrichum corchori, Macrophomina phaseolina, Fusarium spp., and Botryodiplodia theobromae and least seed-borne fungi were found in the variety of Tossapat while highest infection found in Deshipat. It also revealed that the extract of Garlic, Allamanda and Biskatali had strong ability to control the seed borne diseases of Jute.

\section{Conflicts of Interest}

The authors declare no conflicts of interest regarding the publication of this paper.

\section{References}

[1] Hossain, M.M. and Abdulla, F. (2015) Jute Production in Bangladesh: A Time Series Analysis. Journal of Mathematics and Statistics, 11, 93-98. https://doi.org/10.3844/jmsspp.2015.93.98

[2] Sarker, M.N.I., Barman, S.C., Islam, M. and Islam, R. (2017) Role of Lemon (Citrus Limon) Production on Livelihoods of Rural People in Bangladesh. Journal of Agricultural Economics and Rural Development, 2, 167-175.

[3] Islam, M.S., Ali, M.A. and Sarker, M.N.I. (2015) Efficacy of Medicinal Plants against Seed Borne Fungi of Wheat Seeds. International Journal of Natural and Social Sciences, 2, 48-52.

[4] Sarker, M.N.I. and Sultana, A. (2017) An Investigation into the Status of Riverbank (Char) Women Dwellers in Bangladesh. International Journal of Rural Development, Environment and Health Research (IJREH), 1, 86-92.

[5] Rathod, L.R. and Pawar, P.V. (2012) Antimicrobial Activity of Medicinal Plant to Control Seed Borne Pathogen of Soybean. Current Botany, 3, 10-12.

[6] Lecomte, C., Alabouvette, C., Edel-Hermann, V., Robert, F. and Steinberg, C. (2016) Biological Control of Ornamental Plant Diseases Caused by Fusarium oxysporum: A Review. Biological Control, 101, 17-30. https://doi.org/10.1016/j.biocontrol.2016.06.004

[7] Ali, M.A., Islam, M.S., Sarker, M.N.I. and Bari, M.A. (2015) Study on Biology of Red Pumpkin Beetle in Sweet Gourd Plants. International Journal of Applied Research Journal, 2, 1-4.

[8] Sarker, M.N.I., Ali, M.A., Islam, M.S. and Bari, M.A. (2016) Feeding Behavior and Food Preference of Red Pumpkin Beetle, Aulacophora Foveicollis. American Journal of Plant Biology, 1, 13-17.

[9] Sardrood, B.P. and Goltapeh, E.M. (2018) Effect of Agricultural Chemicals and Or- 
ganic Amendments on Biological Control Fungi. In: Lichtfouse, E., Ed., Sustainable Agriculture Reviews, Vol. 12, Springer, Berlin, 217-359.

[10] Sarker, M.N.I. (2016) Role of Banks on Agricultural Development in Bangladesh. International Journal of Ecology and Development Research, 1, 10-15.

[11] Islam, M.J., Akanda, A.M., Bhuiyan, M.K.A. and Haque, A.H.M.M. (2018) Integrated Management against Seed-Borne Diseases of Farmers Stored Chickpea. Global Journal of Science Frontier Research: D Agriculture and Veterinary, 18, 23-30.

[12] Haider, M.K., Islam, M.S., Islam, S.S. and Sarker, M.N.I. (2015) Determination of Crop Coefficient for Transplanted Aman Rice. International Journal of Natural and Social Sciences, 2, 34-40.

[13] Sarker, M.N.I., Ali, M.A. and Islam, M.S. (2015) Causes and Possible Solutions of Poverty Perceived by Char Dwellers in Bangladesh. International Journal of Natural and Social Sciences, 2, 37-41.

[14] Islam, M.S., Khanam, M.S. and Sarker, M.N.I. (2018) Health Risk Assessment of Metals Transfer from Soil to the Edible Part of Some Vegetables Grown in Patuakhali Province of Bangladesh. Archives of Agriculture and Environmental Science, 3, 187-197. https://doi.org/10.26832/24566632.2018.0302013

[15] Islam, M.S., Proshad, R., Asadul Haque, M., Hoque, F., Hossin, M.S. and Sarker, M.N.I. (2018) Assessment of Heavy Metals in Foods around the Industrial Areas: Health Hazard Inference in Bangladesh. Geocarto International, 33, 1016-1045. https://doi.org/10.1080/10106049.2018.1516246

[16] Ahmad, L., Pathak, N. and Zaidi, R.K. (2016) Antifungal Potential of Plant Extracts against Seed-Borne Fungi Isolated from Barley Seeds (Hordeum vulgare L.). Journal of Plant Pathology \& Microbiology, 7, 5-8. https://doi.org/10.4172/2157-7471.1000350

[17] Sarker, M.N.I. (2016) Poverty of Island Char Dwellers in Bangladesh. Diplomica Publishing GmbH, Hamburg.

http://www.anchor-publishing.com/e-book/318628/poverty-of-island-char-dwellers -in-bangladesh

[18] Gawade, S.B., Zanjare, S.R., Suryawanshi, A.V. and Shelar, V.R. (2016) Efficacy of Bioagents and Botanicals on Seed Mycoflora and Seed Quality in Mungbean. Agricultural Science Digest-A Research Journal, 35, 30-34.

[19] ISTA (2017) Rules Proposals for the International Rules for Seed Testing 2018 Edition. International Seed Testing Association (ISTA), Bassersdorf.

[20] Kuri, S.K. and Mondal, U. (2011) Antifungal Potentiality of Some Botanical Extracts against Important Seedborne Fungal Pathogen Associated with Brinjal Seeds, Solanum melongena L. Journal of Agricultural Technology, 7, 1139-1153.

[21] Islam, M.S., Sarker, M.N.I. and Ali, M.A. (2015) Effect of Seed Borne Fungi on Germinating Wheat Seed and Their Treatment with Chemicals. International Journal of Natural and Social Sciences, 2, 28-32.

[22] Mehedi, I., Sultana, A. and Raju, M.A.U. (2016) Control of Seed Borne Fungi on Tomato Seeds and Their Management by Botanical Extracts. Research in Agriculture, Livestock and Fisheries, 3, 403-410. https://doi.org/10.3329/ralf.v3i3.30731

[23] Srivastava, R.K., Singh, R.K., Kumar, N. and Singh, S. (2010) Management of Macrophomina Disease Complex in Jute (Corchorus olitorius) by Trichoderma viride. Journal of Biological Control, 24, 77-79.

[24] Islam, M. (2014) Research Advances of Jute Field Weeds in Bangladesh: A Review. 
ARPN Journal of Science and Technology, 4, 254-268.

[25] Chellappandian, M., Vasantha-Srinivasan, P., Senthil-Nathan, S., Karthi, S., Thanigaivel, A., Ponsankar, A., Hunter, W.B., et al. (2018) Botanical Essential Oils and Uses as Mosquitocides and Repellents against Dengue. Environment International, 113, 214-230. https://doi.org/10.1016/j.envint.2017.12.038

[26] Li, X.Z., Song, M.L., Yao, X., Chai, Q., Simpson, W.R., Li, C.J. and Nan, Z.B. (2017) The Effect of Seed-Borne Fungi and Epichloë Endophyte on Seed Germination and Biomass of Elymus sibiricus. Frontiers in Microbiology, 8, 1-8. https://doi.org/10.3389/fmicb.2017.02488

[27] Perelló, A., Gruhlke, M. and Slusarenko, A.J. (2013) Effect of Garlic Extract on Seed Germination, Seedling Health, and Vigour of Pathogen-Infested Wheat. Journal of Plant Protection Research, 53, 317-323. https://doi.org/10.2478/jppr-2013-0048

[28] Hossen, M.T., Sohag, M.A.S. and Monjil, M.S. (2017) Comparative Efficacy of Garlic, BAU-Biofungicide, Bavistin and Tilt on Seed Borne Fungal Flora in Chilli. Bangladesh Journal of Agricultural University, 15, 41-46. https://doi.org/10.3329/jbau.v15i1.33528

[29] Sheheli, S. and Roy, B. (2014) Constraints and Opportunities of Raw Jute Production: A Household Level Analysis in Bangladesh. Progressive Agriculture, 25, 38-46. https://doi.org/10.3329/pa.v25i0.24070

[30] Niu, X., Gao, H., Qi, J., Chen, M., Tao, A., Xu, J., Su, J., et al. (2016) Colletotrichum Species Associated with Jute (Corchorus capsularis L.) Anthracnose in Southeastern China. Scientific Reports, 6, Article No. 25179.

[31] Meena, P.N., Roy, A., Gotyal, B.S., Mitra, S. and Satpathy, S. (2014) Eco-Friendly Management of Major Diseases in Jute (Corchorus olitorius L.). Journal of Applied and Natural Science, 6, 541-544. https://doi.org/10.31018/jans.v6i2.496

[32] Derbel, S., Touzard, B., Triki, M.A. and Chaieb, M. (2010) Seed Germination Responses of the Saharan Plant Species Ephedra alata sspp. Alenda to Fungicide Seed Treatments in the Laboratory and the Field. Flora: Morphology, Distribution, Functional Ecology of Plants, 205, 471-474. 